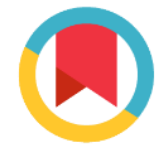

Check for updates

*For correspondence:

drbphuong@gmail.com

Competing interests: The authors declare that no competing interests exist.

Received: 2017-02-07

Accepted: 2017-08-25

Published: 2017-09-05

Copyright The Author(s) 2017. This article is published with open access by BioMedPress (BMP).

This article is distributed under the terms of the Creative Commons Attribution License (CC-BY 4.0) which permits any use, distribution, and reproduction in any medium, provided the original author(s) and the source are credited.

\section{Allogenic mesenchymal stem cell transplantation for chronic obstructive pulmonary disease}

\author{
Le Thi-Bich Phuong
}

Van Hanh Stem Cell Unit, Van Hanh General Hospital, Ho Chi Minh City, Vietnam

\section{Abstract}

Background: Chronic obstructive pulmonary disease (COPD) is the chronic condition in which there is progressive obstruction of air flow in and out of the lungs. COPD is characterized by inflammation and its intensification with the participatation of immune cells. Currently, there is no effective treatment and the goal of COPD treatment is relieve the symptomps and improve quality of life. The prevalence and mortality rate increase rapidly annual leads COPD to the third leading cause of death worldwide.

Stem cell based therapy offers a promising approach to COPD. The main mechanism of stem cell based therapy is capacity of immunomodulation, bacterial clearance, hypertension pulmonary pressure reversal and others.

Method: We conduct the clinical trial using allogenic umbilical cord mesenchymal stem cell in 10 patients with COPD stage $C$ and $D$. Route of administration is intravenously infusion. Dose of infusion is $1,5 \times 10^{\wedge} 6$ cells $/ \mathrm{kg}$ of weight. We follow the safety and efficacy during 6 months by index od SAEs, the number of COPD attacks, CAT, mMRC score, 6minute walking test, hsCRP and Spirometry.

Result: The improvement of patient's condition happens after 1 month after stem cell infusion. The amelioration lasts up to 6 month follow up which expressed by clinical index, FEV 1 and hsCRP. Besides, there is no serious adverse effects happens.

Conclusion: Allogenic umbilical cord mesenchymal stem cell is proven to be safe in COPD patients. Our trial shows the initial efficacy in COPD treatment. We need more strong evidence to support this approach.

\section{Keywords}

\section{Funding}

\section{References}

